\title{
Antimicrobial Copper Foil Reduces Bacterial Contamination and Load on Door Handles of Loyola Marymount University Dormitory
}

\author{
Kenneth Lu, MD ${ }^{1,2 *}$ and Nicolas Mendez ${ }^{2}$ \\ ${ }^{1}$ University of California, Los Angeles, USA \\ ${ }^{2}$ Clean Copper, LLC, USA \\ *Corresponding author: Kenneth Lu, MD University of California, Los Angeles, USA
}

ARTICLE INFO

Received: 㓞 September 26, 2019

Published: October 10, 2019

Citation: Kenneth Lu, MD, Nicolas Mendez. Antimicrobial Copper Foil Reduces Bacterial Contamination and Load on Door Handles of Loyola Marymount University Dormitory. Biomed J Sci \& Tech Res 21(5)-2019. BJSTR. MS.ID.003663.

\section{ABSTRACT}

Purpose: To demonstrate reduced bacterial contamination and load on door handles outfitted with antimicrobial copper foil as compared to stainless steel handles in a university dormitory.

Methods: Antimicrobial copper foil containing 99.4\% copper was adhered to 5 hallway door handles of dormitory rooms, 1 emergency exit push bar door handle, 1 internal front door push bar door handle, and 1 external front door handle. After 1 month of regular use, the surfaces were swabbed, immediately placed in medium, and cultured for 24 hours. For control, 5 hallway door handles, 1 restroom handle in the same wing of the dormitory, and 1 emergency exit push bar handle of the same dormitory were also swabbed and cultured.

Outcome Measure: Rate of contamination and number of bacterial colonies forming units (CFU) were measured.

Results: Of the 8 copper surfaces, only 1 swab grew 1 CFU, while the rest showed no growth. Of the 7 non-copper surfaces, 5 swabs tested positive for bacterial load, while 2 showed no growth. The 5 positive swabs grew a total of 46 colony forming units. The contamination rate was significantly higher in the non-copper group $(71.4 \%)$ vs. copper group $(12.5 \%)$ by Fisher Exact Test $(\mathrm{p}=0.041)$ and they had significantly higher number of bacterial loads (mean of 6.6 vs. 0.1 ) by Kruskal-Wallis test ( $\mathrm{p}=0.0182$ ).

Conclusion: A novel method of employing antimicrobial copper reduced bacterial contamination and load on frequently touched surfaces in a university dormitory and may prevent spread of disease.

\section{Background}

It is well known and established that copper has antimicrobial effect on bacteria, virus, and fungi [1-3]. Most facilities use solid copper alloys in hospital settings [4,5]. One ingenious study examined contamination rates on copper alloy vs. stainless steel pens used by nurses in a hospital critical care unit [6]. To date, no studies on in vivo antimicrobial copper has used thin foils of copper. For this study, we used a proprietary design (Clean Copper, LLC, Los Angeles, CA) of a 50 micron thin copper foil, which contained 99.4\% copper, with adhesive back that can be customized to the size and shape of different objects to provide a new copper surface. This method minimizes the amount of copper used and is therefore much more cost-effective. It is also less disruptive to patient care or normal conduct of business in any setting. As an example, the setting for the current study, Loyola Marymount University (LMU) was not required to replace any already-existing fixtures in the dormitory. A single technician was able measure, customize and apply all the copper foils in about an hour's time without disrupting student living activities or facilities maintenance. 
Another benefit of using copper foil is that the copper content can be pushed all the way up to almost pure copper. The flexibility of the metal is actually desired in a foil form as opposed to in alloy form for replacing existing solid parts. The advantages of this antimicrobial copper system could make much wider use practical and cost-effective. As already mentioned, the knowledge regarding copper's antimicrobial property is widely known. The ancient Egyptians stored drinking water in copper jugs to prevent diarrhea [7]. The U.S. Environmental Protection Agency recognized copper as antimicrobial in 2008 [8], being able to "kill 99.9\% of bacteria in less than 2 hours." Yet, antimicrobial copper is not widely used for this purpose due to the cost and disruption of replacing existent parts and fixtures. The present study examines a novel system of using copper to fight infections and contagions. The LMU setting was selected as a common setting where presumably healthy, young people congregated. The microcosm found on a door handle their mirrors millions of doors handles anywhere else. This provides a real-life scenario where the interaction of copper and microbes could have wide applications in everyday life.

\section{Methods}

This study was approved by LMU Facilities Management. The west wing of Desmond Residence was selected as the test facility. 5 door handles on one side of the hallway was measured, customized, and applied with Clean Copper, LLC (Los Angeles, CA) antimicrobial copper foil (99.4\% copper, $0.6 \%$ nickel). In addition, the emergency exit push bar handle at the end of the hallway, the internal push bar and the external door handle of the front door were covered with copper as well. This was performed by a single technician over a two-day period, taking a total of about an hour. Photographs of the copper-covered handles are shown in (Figures 1-3). After installation, the copper and regular surfaces were maintained in the same fashion per routine. House staff would clean the facilities on the usual schedule. The only difference is that the copper surface required a weak acid wipe about once a month or so to prevent tarnishing. This was done at least one week prior to the swab test. One month after installation, swabbing of the copper and control surfaces were performed at 9:30AM on a weekday. The hallway was completely empty for at least half hour prior to testing. No students or staff members came in or out of the rooms during the swab test. The handles were swiped along its entire length 5 times with sterile testing swabs. The distal $2 \mathrm{~cm}$ of the swabs were cut in a touch-less fashion and placed in $2 \mathrm{ml}$ of neutralizing solution (D/E neutralizing broth; BD, Franklin Lakes, NJ) and vortexed for 60 seconds. Then 500 ul of this solution was inoculated onto the surface of a blood agar plate and incubated aerobically at $370 \mathrm{C}$ for 24 hours. All microorganisms were enumerated and identified using standard microbiological techniques.
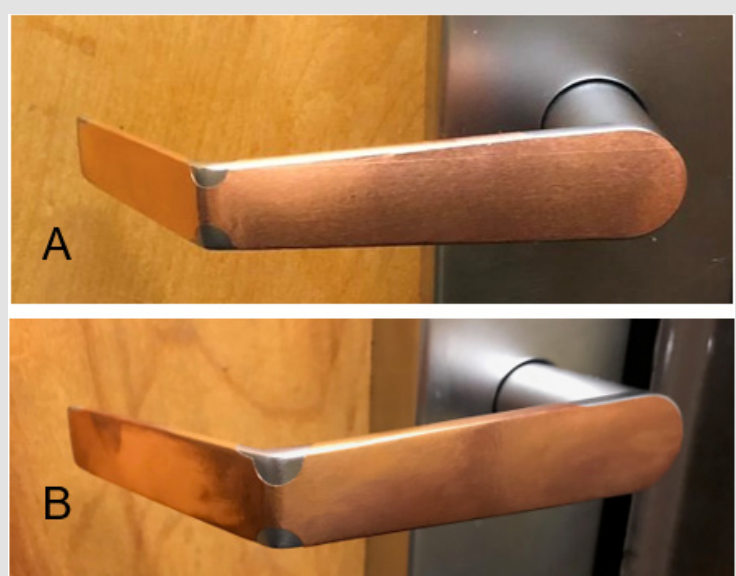

Figure 1: Dorm room handle. A is immediately after copper installation. B is 1 month later.
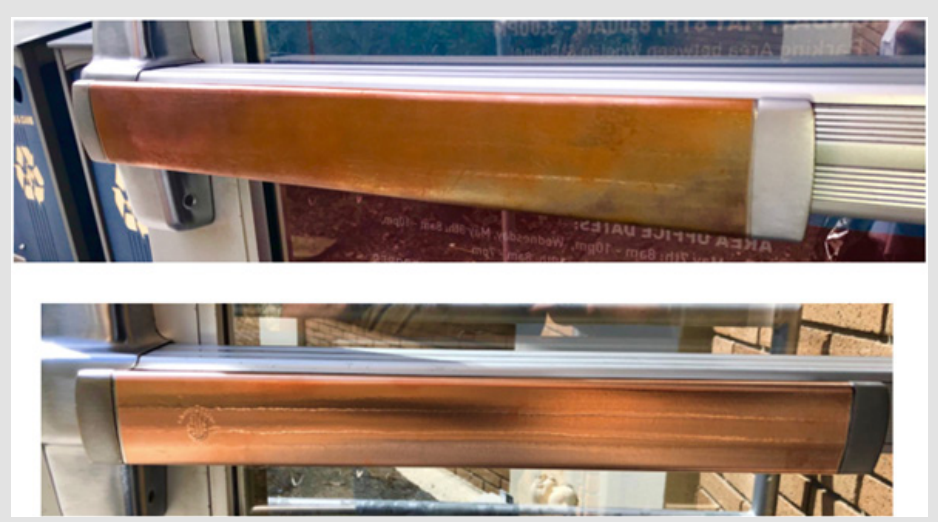

Figure 2: Front entrance push bar handle. A. Immediately upon installation. B. 1 month after. 

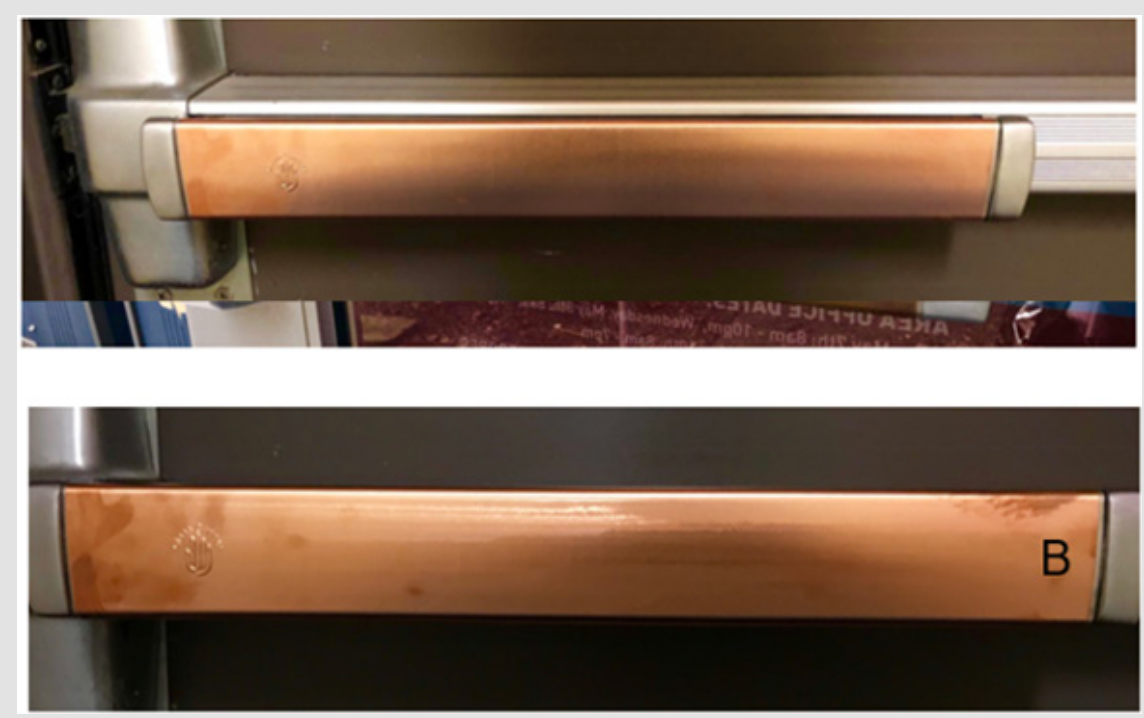

Figure 3: Emergency push bar handle. A. Immediately upon installation. B. 1 month after.

\section{Results}

The number of surfaces contaminated with microorganisms and the number of CFU recovered are presented in Tables $1 \& 2$, respectively. Of the 8 copper surfaces, only 1 swab grew $1 \mathrm{CFU}$, while the rest showed no growth. Of the 7 non-copper surfaces, 5 swabs tested positive for bacterial contamination, while 2 showed no growth. The 5 positive swabs grew a total of $46 \mathrm{CFU}$. The contamination rate was significantly higher in the non-copper group (71.4\%) vs. copper group (12.5\%) by Fisher Exact Test (p $=0.041$ ) and they had statistically significantly higher number of bacterial loads as measured in CFU (mean of 6.6 vs. 0.1) by KruskalWallis test $(\mathrm{p}=0.0182)$. The bacteria cultured were staphylococci coagulase negative, diphtheroid, and non-cereus or anthracis bacillus species. 3 of the non-copper surfaces grew multiple species of bacteria, while the rest cultured 1 type of bacteria. The Resident Assistant's door handle and the hallway exit push bar handle contained the highest CFU. No antibiotic sensitivity testing was performed since these were commensal organisms. During the month of installation there were no complaints from the student body or staff regarding the copper. The aesthetic appearance was well maintained with the infrequent maintenance wipe. Student and staff activities were not disrupted in any perceivable way.

Table 1: Number of surfaces contaminated with bacteria.

\begin{tabular}{|c|c|c|}
\hline $\begin{array}{c}\text { Stainless Steel Surface } \\
\text { Contamination (\%) }\end{array}$ & $\begin{array}{c}\text { Copper Surface } \\
\text { Contamination (\%) }\end{array}$ & $\begin{array}{c}\text { P value, Fisher's } \\
\text { exact test }\end{array}$ \\
\hline 71.4 & 12.5 & $\mathbf{0 . 0 4 1}$ \\
\hline
\end{tabular}

Table 2: Number of CFU recovered from copper vs. regular surfaces.

\begin{tabular}{|c|c|c|c|}
\hline & $\begin{array}{c}\text { Stainless Steel } \\
\text { Surface }\end{array}$ & $\begin{array}{c}\text { Copper } \\
\text { Surface }\end{array}$ & $\begin{array}{c}\text { P value, Kruskal- } \\
\text { Wallis test }\end{array}$ \\
\hline Mean CFU & 6.6 & 0.1 & 0.0182 \\
\hline Standard Deviation & 12.7 & 0.4 & \\
\hline
\end{tabular}

\section{Discussion}

The present study is the first known instance of a university dormitory utilizing copper foil surfacing on fixtures to reduce bacterial burden and exposure to students and staff. The ingenious system of 50 um thin copper foil minimizes the amount of copper to just the surface, thus reducing the cost to the bare minimum. It is also a very practical solution, covering the intended environment instead of replacing fixtures that are for the most part already in place. And as is shown in the swab testing, the copper is highly effective in limiting the amount of bacterial growth, with bacterial contamination rate being about 6 times and bacterial load 66 times higher in regular surface as compared to the copper-covered surface. The difference was so dramatic between the two groups that only a small sample size was required to achieve a high level of statistical significance. Even though the bacteria identified in this particular study were all commensal organisms, these can sometimes cause infections as well. Also, it is only a small corner of the university that was tested. If the entire university was tested, more harmful pathogens would undoubtedly to found.

Studies have shown that dangerous bacteria such as MRSA is found in $30-37 \%$ of hospital population and $1.3 \%$ of community population [9]. These bacteria are left on touched surfaces, survive for weeks to months [10], then are picked up by other people. Having copper surfaces helps to reduce contamination rate by 6 -fold and bacterial loads to by 66 fold. Since bacteria is the direct cause of infections, having more copper-covered surfaces should reduce the rate of infections. Indeed, a prospective, randomized study [11] has already demonstrated that just having 6 items of copper in an ICU room can reduce the rate of hospital acquired infection (HAI) by 58\%. Even though a university setting may not harbor as much dangerous pathogens as a hospital, if copper can be employed in a cost-effective manner, comparable to cost of 
cleaning regular surfaces, it is worthwhile to provide as hygienic an environment as possible. Also, the present study only addressed bacterial load. Copper has been shown to be highly effective against viruses as well. It can help to reduce the spread of the common cold and flu, which has been particularly deadly the last couple of years. Sadly, young, healthy patients can and have died from the flu all too often. In conclusion, the present study demonstrated a novel method of employing antimicrobial copper in reducing bacterial contamination and load on commonly touched surfaces in a university dormitory.

\section{Acknowledgement}

The authors would like to thank David French, Martin Alvarez, Beth Crowell, Sandra Seisdedos, Michael Ishino, and Juan DeAnda at LMU for their assistance with the project.

\section{References}

1. Barchiesi F, Silvestri C, Arzeni D, Ganzetti G, Castelletti S, et al. (2009) In vitro susceptibility of dermatophytes to conventional and alternative antifungal agents. Med Mycology 47(3): 321-326.

2. Noyce JO, Michels H, Keevil CW (2007) Inactivation of Influenza A Virus on Copper versus Stainless Steel Surfaces. App Enviro Micro 73(8): 2748-2750.

3. Karpanen TJ, Casey AL, Lambert PA, Cookson BD, Nightingale P, et al. (2012) The Antimicrobial Efficacy of Copper Alloy Furnishing in the

ISSN: 2574-1241

DOI: 10.26717/BJSTR.2019.21.003663

Kenneth Lu, MD. Biomed J Sci \& Tech Res

(C) This work is licensed under Creative

Submission Link: https://biomedres.us/submit-manuscript.php
Clinical Environment: A Crossover Study. infect Control Hospital Epidem 33(1): 5-9.

4. Schmidt MG, Attaway HH, Sharpe PA, Joseph John, Kent A Sepkowitz, et al. (2012) Sustained Reduction of Microbial Burden on Common Hospital Surfaces through Introduction of Copper. J Clin Microbiology 50(7): 2217-2223.

5. Schmidt MG, Attaway HH, Fairey SE, Steed LL, Michels HT, et al. (2013) Copper Continuously Limits the Concentration of Bacteria Resident on Bed Rails within the Intensive Care Unit. Infect Control Hosp Epidemiol 34(5): 530-533.

6. Casey AL, Karpanen TJ, Adams D, Lambert PA, Nightingale P, et al. (2011) A comparative study to evaluate surface microbial contamination associated with copper-containing and stainless-steel pens used by nurses in the critical care unit. Am J Infect Control 39(8): 52-54.

7. Dollwet, HA, Sorenson JR (1985) Historic uses of copper compounds in medicine. Trace Elem Med 2: 80-87.

8. Prado JV, Vidal AR, Duran TC (2012) Application of copper bactericidal properties in medical practice. Rev Med Chil 140(10): 1325-1332.

9. Salgado CD, Farr BM, Calfee DP (2003) Community-Acquired MethicillinResistant Staphylococcus aureus: A Meta-Analysis of Prevalence and Risk Factors. Clin Infect Dis 36(2): 131-139.

10. Neely AN, Maley MP (2000) Survival of Enterococci and Staphylococci on Hospital Fabrics and Plastic. J Clin Microbiol 38(2): 724-726.

11. Salgado CD, Sepkowitz KA, John JF, Cantey JR, Attaway HH, et al. (2013) Copper Surfaces Reduce the Rate of Healthcare-Acquired Infections in the Intensive Care Unit. Infect Control Hosp Epidemiol 34(5): 479-486.

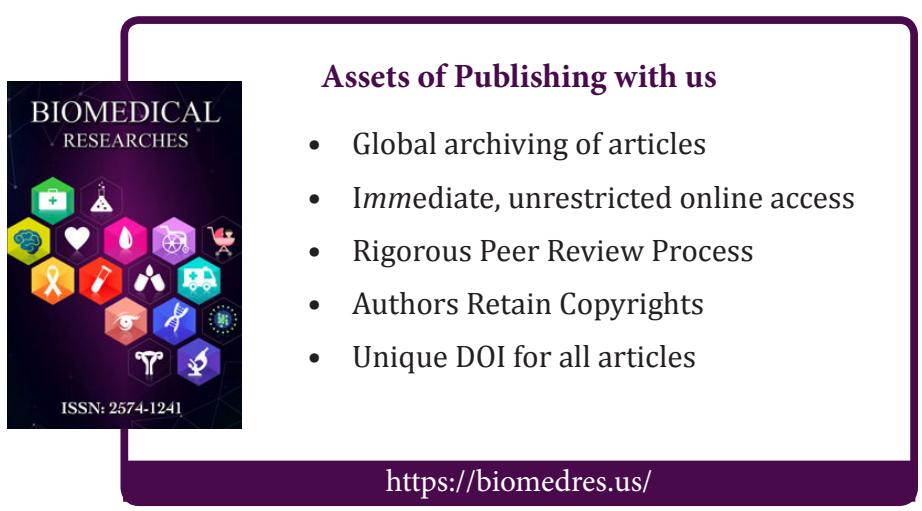

